\title{
HUBUNGAN KOMUNIKASI ORGANISASI DENGAN KINERJA PEGAWAI DI DINAS KEPENDUDUKAN DAN PENCATATAN SIPIL KOTA BANJARMASIN
}

\author{
Muhammad Agus Humaidi \\ Universitas Islam Kalimantan Muhammad Arsyad Al Banjari Banjarmasin \\ E-mail : m.agus.humaidi@gmail.com
}

\begin{abstract}
ABSTRAK
Penelitian ini bertujuan untuk mengetahui komunikasi organisasi dan kinerja pegawai pada Dinas Kependudukan dan Pencatatan Sipil Kota Banjarmasin, selain itu untuk mengetahui hubungan komunikasi organisasi dengan kinerja pegawai pada Dinas Kependudukan dan Pencatatan Sipil Kota Banjarmasin. Metode yang digunakan adalah pendekatan penelitian kuantitatif dan instrumen penelitian dengan kuesioner dianalisis dengan Chi Square Goodness Of Fit dan Pearson Correlation. Hasil penelitian menunjukkan bahwa komunikasi organisasi pegawai pada Dinas Kependudukan dan Pencatatan Sipil Kota Banjarmasin tergolong cukup baik. Sedangkan kinerja pegawai pada Dinas Kependudukan dan Pencatatan Sipil Kota Banjarmasin berada pada kategori baik. Selain itu, terdapat hubungan antara komunikasi organisasi dengan kinerja pegawai pada Dinas Kependudukan dan Catatan Sipil Kota Banjarmasin.
\end{abstract}

Kata Kunci : Komunikasi Organisasi, Kinerja Karyawan

\section{PENDAHULUAN}

Semua organisasi tentunya memerlukan sumber daya agar tercapainya tujuan dari organisasi tersebut. Sumber daya tersebut terdiri dari sumber daya alam, sumber daya finansial, sumber daya manusia, sumber daya ilmu pengetahuan, dan sumber daya teknologi. Diantara sumber daya tersebut, sumber daya yang terpenting adalah sumber daya manusia (SDM). Tanpa sumber daya manusia (SDM), sumber daya lainnya menganggur (idle) dan kurang bermanfaat dalam mencapai tujuan yang diharapkan organisasi. Secara lebih tegas dikatakan bahwa "Tingkat efektivitas manajemen sumber daya manusia dipandang turut mempengaruhi kinerja suatu organisasi, sebesar atau sekecil apapun organisasi tersebut" (Malthis dan Jackson, 2001).

organisasi pemerintahan maupun

perusahaan sama-sama menbutuhkan peranan komunikasi dalam aktifitasnya guna mencapai tujuan yang telah direncanakan sebelumnya. Pemimpin dalam sebuah organisasi diharapkan agar selalu memperhatikan bagaimana keadaan situasi kerja bawahan yang dipimpinnya agar dapat mengetahui tuntutan atau keluhan pegawai sehingga tercapai efesiensi kerja. Untuk itu seorang pemimpin organisasi perlu menumbuhkan dan memelihara komunikasi yang efektif dengan seluruh anggota organisasi.

Komunikasi antara pegawai dengan atasan, atasan dengan pegwai maupun pegawai sesama pegawai yang berjalan dengan baik, hal tersebut akan berdampak positif terhadap kinerja pegawai. Menurut Putu Sunarcaya (2008), komunikasi organisasi merupakan salah satu faktor yang dapat digunakan untuk menigkatkan kinerja pegawai.

Kinerja pegawai dianggap penting bagi organisasi karena keberhasilan suatu organisasi dipengaruhi oleh kinerja itu sendiri. Menurut Rivai (2004), kinerja merupakan perilaku nyata yang ditampilkan setiap orang sebagai prestasi kerja yang dihasilkan oleh karyawan sesuai dengan perannya dalam organisasi. Selain itu, Kinerja atau prestasi kerja adalah hasil kerja yang dicapai oleh seorang pegawai dalam melakukan tugas sesuai tanggung jawab yang diberikan kepadanya (Mangkunegara, 2000).

Komunikasi organisasi dengan kinerja tampaknya memiliki hubungan hal ini dapat diketahui dari hasil penelitian dari Arif Sehfudin (2011) menyatakan bahwa adanya pengaruh antara komunikasi organisasi terhadap kinerja karyawan pada PT Bank Tabungan Pensiunan Nasional 
Semarang. Selain itu dari hasil penelitian Agus Budhi Haryanto (2010) menyatakan bahwa komunikasi berpengaruh positif dan signifikan terhadap kinerja pegawai Pegawai Dinas Pendidikan Kabupaten Sukoharjo. Serta Lili Wahyuni (2009) dalam hasil penelitiannya menemukan bahwa Ada pengaruh yang signifikan antara komunikasi organisasi terhadap kinerja Karyawan Bagian Akuntansi.

Dinas Kependudukan dan Pencatatan Sipil

Kota Banjarmasin dibentuk berdasarkan Peraturan Daerah Kota Banjarmasin Nomor 15 Tahun 2008. Layanan yang di berikan oleh seluruh pegawai Dinas Kependudukan dan Pencatatan Sipil Kota Banjarmasin, diantaranya adalah penerbitan kartu keluarga, surat keterangan pindah, surat kartu keluarga pindah datang, perekaman atau penerbitan KTP-EL, akta kelahiran, akta kematian, akta perceraian dan akta pernikahan. Selain itu adanya layanan terbaru Disdukcapil Kota Banjarmasin seperti Luntang Lantung yang merupakan singkatan dari Ulun Datang Langsung Tuntung dan juga layanan One Day Service yaitu sebagai cara untuk memaksimalkan pelayanan namun hal ini masih kurang karena perlu didukung dengan SDM yang memiliki kinerja yang maksimal agar terciptanya produktivitas kerja yang optimal.

Berdasarkan temuan penulis ada beberapa fenomena yang terjadi pada saat peneliti melakukan observasi di Dinas Kependudukan dan Pencatatan Sipil Kota Banjarmasin seperti masih kurangnya komunikasi yang efektif antara beberapa pegawai hal ini dapat terlihat dalam pemberian tugas yang diberikan atasan, pegawai lama tidak berperan aktif dalam hal ini untuk memberikan masukan kepada pegawai yang sifatnya masih baru. Dapat dilihat dari jarangnya pegawai bertukar fikiran/berdiskusi mengenai pekerjaan. Penyelesaian pekerjaan menjadi kurang lancar karena kurangnya team work diantara mereka. Serta terdapat situasi dimana kesempatan pegawai untuk berkomunikasi dengan atasan terbatas sehingga berdampak terhadap ketidak lancaran intensitas komunikasi dua arah dan berakibat terhadap penyelesaian pekerjaan.

Dari beberapa fenomena yang terjadi diatas tampaknya disebabkan oleh komunikasi organisasi yang belum begitu baik. Oleh sebab itu, hal ini bermakna bahwa penerapan komunikasi yang baik di Dinas Kependudukan dan Pencatatan Sipil Kota Banjarmasin belum berjalan secara optimal. Melihat pengaruh yang sangat penting antara proses komunikasi yang terjadi dalam suatu organisasi antara pegawai dengan tingkat kinerja pegawai maka penulis tertarik mengambil judul "Hubungan Komunikasi Organisasi dengan Kinerja Pegawai di Dinas Kependudukan dan Pencatatan Sipil Kota Banjarmasin".

\section{TINJAUAN PUSTAKA}

\section{Komunikasi Organisasi}

Pengertian komunikasi organisasi oleh Goldhaber adalah"Proses menciptakan dan saling menukar pesan dalam satu jalinan hubungan yang saling tergantung satu sama lain untuk mengatasi lingkungan yang tidak pasti atau selalu berubahubah (Muhammad, 2007). Sedangkan pengertian komunikasi Organisasi menurut Zelko dan Dance dalam Muhammad (2007) adalah: "Suatu sistem yang saling tergantung yang mencakup komunikasi internal dan komunikasi eksternal". Komunikasi internal menurut Zelko dan Dance adalah komunikasi dalam Organisasi itu sendiri seperti komunikasi dari bawahan kepada atasan, komunikasi sesama karyawan yang sama tingkatan, sedangkan komunikasi eksternal adalah komunikasi yang dilakukan organisasi terhadap lingkungan kerja, seperti komunikasi penjualan hasil produksi dan lain-lain.

Penelitian ini menggunakan pendapat Rohim (2009) untuk mengukur komunikasi organisasi pegawai di Dinas Kependudukan dan Pencatatan Sipil Kota Banjarmasin, antara lain : 1) komunikasi dari atas ke bawah (downward communication), 2) komunikasi dari bawah ke atas (upward communication) dan 3) komunikasi horisontal (horizontal communication).

\section{Kinerja}

Secara etimologi, kinerja berasal dari kata prestasi kerja (performance). Sebagaimana dikemukakan oleh Mangkunegara dalam Widodo (2015) bahwa istilah kinerja dari kata job performance atau actual performance (prestasi kerja atau prestasi sesungguhnya yang dicapai oleh seseorang) yaitu hasil kerja secara kualitas dan kuantitas yang dicapai oleh seseorang pegawai dalam melaksanakan tugasnya sesuai dengan tanggung jawab yang diberikan padanya. Sedangkan Fahmi (2016) kinerja adalah hasil yang diperoleh oleh suatu organisasi tersebut bersifat profiet oriented dan non oriented yang dihasilkan selama satu periode waktu.

Penelitian ini menggunakan pendapat Robbins (2006) untuk mengukur kinerja pegawai di Dinas Kependudukan dan Pencatatan Sipil Kota Banjarmasin, yaitu: 1) Kualitas, 2) Kuantitas, 3) Ketepatan Waktu, 4) Efektivitas dan 5) Kemandirian. 


\section{Hubungan Komunikasi Organisasi dengan Kinerja Pegawai}

Salah satu data pendukung yang menurut peneliti perlu dijadikan bagian tersendiri adalah penelitian terdahulu yang relevan dengan permasalahan yang sedang dibahas dalam penelitian ini. Dalam hal ini, fokus penelitian terdahulu yang dijadikan acuan adalah terkait dengan hubungan komunikasi organisasi terhadap kinerja. Oleh karena itu, peneliti melakukan langkah kajian terhadap beberapa hasil penelitian berupa jurnal-jurnal melalui internet. Berdasarkan hasil-hasil penelitian yang telah dilakukan menyiratkan bahwa variabel komunikasi organisasi berhubungan dengan kinerja. Seperti hasil penelitian sebagai berikut:

"Terdapat hubungan yang kuat dari variabel bebas (X) yaitu komunikasi organisasi terhadap variabel tidak bebas $(\mathrm{Y})$ yaitu kinerja karyawan"

Dari hasil penelitian tersebut, maka dapat ditarik kesimpulan bahwa dengan komunikasi organisasi yang baik maka kinerja pegawai akan meningkat. Begitu juga sebaliknya, jika komunikasi organisasi kurang baik maka kinerja akan turun juga. Jadi dengan kata lain komunikasi organisasi akan berpengaruh terhadap kinerja pegawai.

\section{Kerangka Berfikir}

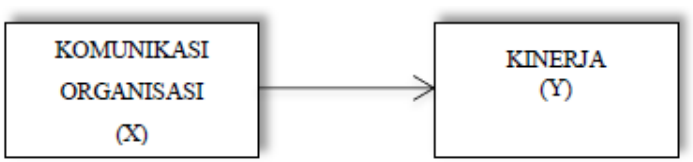

Gambar 2.2. Kerangka Pemikiran Penelitian

Komunikasi Organisasi (X) sebagai variabel independen (variabel bebas) mempengaruhi variabel dependen (variabel terikat) Kinerja (Y).

\section{Hipotesis}
Hubungan Komunikasi Organisasi dengan
Kinerja
HO : Tidak terdapat hubungan antara Komunikasi Organisasi dengan Kinerja di Dinas Kependudukan dan Pencatatan Sipil Kota Banjarmasin.
H1 : Terdapat hubungan antara Komunikasi Organisasi dengan Kinerja di Dinas Kependudukan dan Pencatatan Sipil Kota Banjarmasin.

\section{METODE PENELITIAN}

\section{Pendekatan Penelitian}

Dalam melakukan penelitian ini penulis memilih jenis penelitian kuantitatif dengan pendekatan survey.

\section{Tipe Penelitian}

Penulis dalam penelitian ini menggunakan metode penelitian deskriptif dan assosiatif.

\section{Lokasi Penelitian}

Penelitian ini dilakukan di Dinas Kependudukan dan Pencatatan Sipil Kota Banjarmasin dengan objek mencakup Hubungan komunikasi organisasi dengan kinerja pegawai di Dinas Kependudukan dan Pencatatan Sipil Kota Banjarmasin.

\section{Populasi dan Sampel}

Populasi dalam penelitian ini adalah seluruh pegawai di Dinas Kependudukan dan Pencatatan Sipil Kota Banjarmasin yang berjumlah 51 orang. Dalam penelitian ini hanya sebagian populasi yang diambil untuk dijadikan sampel. Untuk jumlah sampel yang diperlukan rumus slovin. Jadi, Sampel yang akan diambil dalam penelitian ini 45 responden. Skala yang digunakan dalam penelitian ini adalah Skala Likert.

\section{Teknik Pengumpulan Data}

Untuk memperoleh data di Dinas Kependudukan dan Pencatatan Sipil Kota Banjarmasin, khususnya data primer maka dalam penelitian ini digunakan teknik pengumpulan dengan kuesioner (angket).

\section{Definisi Operasional Variabel}

Untuk memperjelas definisi operasional variabel tersebut, peneliti membuat tabel dimana dalam tabel tersebut terdapat bagian kolom variabel, indikator dan parameter. Berikut tabel dapat dilihat dibawah ini :

\begin{tabular}{|c|c|c|}
\hline Variabel & Indikator & Parameter \\
\hline $\begin{array}{l}\text { Komunikasi Organisasi adalah } \\
\text { komunikasi yang terjadi } \\
\text { pertukaran pesan antar manusia }\end{array}$ & $\begin{array}{l}\text { Komunikasi dari } \\
\text { atas ke bawah } \\
\text { (dowmward } \\
\text { communication) }\end{array}$ & $\begin{array}{l}\text { - Pimpinan memberi } \\
\text { kritik/saran kepada pegawai } \\
\text { - Pimpinan memberikan } \\
\text { pembinaan dan motivasi }\end{array}$ \\
\hline \multirow{3}{*}{$\begin{array}{l}\text { dalam sebuah organisasi yang } \\
\text { saling tergantung guna mencapai } \\
\text { kesamaaan makna. }\end{array}$} & & secara lisan kepada pegawai \\
\hline & $\begin{array}{l}\text { Komunikasi dari } \\
\text { bawah ke atas } \\
\text { (upward } \\
\text { communication) }\end{array}$ & $\begin{array}{l}\text { - Pegawai berbicara dengan } \\
\text { pimpinan cara melaksanakan } \\
\text { tugas yang baik dan } \\
\text { profesional } \\
\text { - Pegawai berdiskusi masalah } \\
\text { pekerjaan kepada pimpinan } \\
\end{array}$ \\
\hline & $\begin{array}{l}\text { Komunikasi } \\
\text { horisontal } \\
\text { (horizontal } \\
\text { communication) }\end{array}$ & $\begin{array}{l}\text { - Pegawai meminta pendapat } \\
\text { kepada rekan kerja } \\
\text { - Pegawai berinteraksi dengan } \\
\text { rekan kerja jam istirahat } \\
\text { - Pegawai berbicara sesama } \\
\text { rekan kerja untuk } \\
\text { menyelesaikan konflik }\end{array}$ \\
\hline \multirow{5}{*}{$\begin{array}{l}\text { Kinerja adalah hasil kerja atas } \\
\text { semua pekerjaan dari seorang } \\
\text { atau sekelompok pegawai secara } \\
\text { kualitas dan kuantitas yang telah } \\
\text { diberikan kepadanya dalam } \\
\text { sebuah organisasi. }\end{array}$} & Kualitas & $\begin{array}{l}\text { - Semua pekerjaan yang selesai } \\
\text { hanya sedikit mendapat } \\
\text { koreksi dari atasan } \\
\text { - Semua pekerjaan hasilnya } \\
\text { baik }\end{array}$ \\
\hline & $>$ Kuantitas & $\begin{array}{l}\text { - Semua pekerjaan dapat } \\
\text { diselesaikan }\end{array}$ \\
\hline & Ketepatan waktu & $\begin{array}{l}\text { - Semua pekerjaan selesai tepat } \\
\text { waktu } \\
\text { - Semua pekerjaan selesai lebih } \\
\text { cepat dari waktu yang } \\
\text { ditentukan }\end{array}$ \\
\hline & Efektivitas & $\begin{array}{l}\text { - Melaksanakan dan } \\
\text { menyelesaikan semua } \\
\text { pekerjaan secara efektif }\end{array}$ \\
\hline & Kemandirian & $\begin{array}{l}\text { - Melaksanakan dan } \\
\text { menyelesaikan pekerjaan } \\
\text { tanpa bantuan orang lain }\end{array}$ \\
\hline
\end{tabular}




\section{Analisa Data}

Untuk menjawab rumusan masalah pertama maupun kedua, sekaligus menjawab hipotesis komunikasi organisasi dan kinerja dalam penelitian ini menggunakan rumus Chi Square Goodness Of Fit. Sedangkan untuk menjawab rumusan masalah ketiga mengenai hubungan variabel $\mathrm{X}$ dengan variabel $\mathrm{Y}$ digunakan statistik Korelasi Pearson.

HASIL PENELITIAN DAN PEMBAHASAN

1. Komunikasi Organisasi Pegawai

Tabel 4.20. Komunikasi Organisasi Pegawai

\begin{tabular}{clcc}
\hline No. & Keterangan & F & \% \\
\hline 1. & Sangat Baik & 1 & 2,2 \\
2. & Baik & 1 & 2,2 \\
3. & Cukup Baik & 32 & 71,1 \\
4. & Kurang & 7 & 15,6 \\
5. & Baik & 4 & 8,9 \\
& Tidak Baik & & \\
\hline & Jumlah & 45 & 100,0 \\
\hline
\end{tabular}

Sumber: Analisa Data Primer 2018

Dari tabel 4.20. tersebut, ternyata kesimpulan disemua kategori komunikasi organisasi pegawai di Dinas Kependudukan dan Pencatatan Sipil Kota Banjarmasin, menunjukan bahwa komunikasi organisasi pegawai di Dinas Kependudukan dan Pencatatan Sipil Kota Banjarmasin Cukup Baik.

\section{Kinerja Pegawai}

Tabel 4.21. Kinerja Pegawai

\begin{tabular}{clcc}
\hline No. & Keterangan & F & \% \\
\hline 1. & Sangat Baik & 4 & 8,9 \\
2. & Baik & 16 & 35,6 \\
3. & Cukup Baik & 12 & 26,7 \\
4. & Kurang & 10 & 22,2 \\
5. & Baik & 3 & 6,7 \\
& Tidak Baik & & \\
\hline & Jumlah & 45 & 100,0 \\
\hline
\end{tabular}

Sumber: Analisa Data Primer 2018

Dari tabel 4.21. tersebut, ternyata kesimpulan disemua kategori kinerja pegawai di Dinas Kependudukan dan Pencatatan Sipil Kota Banjarmasin, menunjukan bahwa kinerja pegawai di Dinas Kependudukan dan Pencatatan Sipil kota Banjarmasin Baik.

\section{Hubungan Komunikasi Organisasi dengan Kinerja Pegawai}

Tabel 4.22. Hubungan Komunikasi Organisasi (X) dengan Kinerja (Y)

\section{Correlations}

\begin{tabular}{llrr} 
& \multicolumn{1}{c}{ X } & \multicolumn{1}{c}{$Y$} \\
\hline$X$ & Pearson Correlation & 1 &, $298^{* *}$ \\
\cline { 2 - 4 } & Sig. (2-tailed) & &, 047 \\
\cline { 2 - 4 } & $\mathrm{N}$ & 45 & 45 \\
\hline $\mathrm{Y}$ & Pearson Correlation &, $298^{* *}$ & 1 \\
\cline { 2 - 4 } & Sig. (2-tailed) &, 047 & \\
\cline { 2 - 4 } & $\mathrm{N}$ & 45 & 45 \\
\hline **. Correlation is significant at the 0.01 level (2- & \\
tailed). &
\end{tabular}

Pada tabel di atas terlihat bahwa nilai korelasi antara komunikasi organisasi dengan kinerja pegawai mempunyai nilai korelasi 0,298 dan nilai probabilitas 0,047. Berdasarkan nilai korelasi 0,298 menunjukan terdapat hubungan atau korelasi antara komunikasi organisasi dengan kinerja, korelasi tersebut mempunyai sifat hubungan Rendah. Hasil probabilitas menunjukan bahwa $0,047<0,05$, hal ini menunjukan bahwa $\mathrm{H} 0$ ditolak, dengan demikian hipotesis $\mathrm{H} 1$ yang menyatakan terdapat hubungan antara komunikasi organisasi dengan kinerja pegawai di Dinas Kependudukan dan Pencatatan Sipil Kota Banjarmasin diterima. Jadi dapat disimpulkan bahwa apabila komunikasi organisasi pegawai membaik maka kinerja pegawai pun ikut membaik, demikian pula sebaliknya bila komunikasi organisasi pegawai kurang baik maka kinerja pegawai pun akan kurang baik.

\section{PENUTUP}

\section{Kesimpulan}

Berdasarkan hasil analisis tentang hubungan komunikasi interpersonal dengan kinerja pegawai di Dinas Kependudukan dan Pencatatan Sipil Kota Banjarmasin maka dapat disimpulkan sebagai berikut:

1) Komunikasi organisasi pegawai di Dinas Kependudukan dan Pencatatan Sipil Kota Banjarmasin, yang termasuk kategori Cukup Baik sebanyak 32 orang $(71,1 \%)$, sedangkan yang kategori Kurang Baik sebanyak 7 orang $(15,6 \%)$, kategori Tidak Baik 4 orang $(8,9 \%)$, sedangkan kategori Sangat Baik sebanyak 1 orang $(2,2 \%)$, sama dengan kategori Baik yaitu 1 orang atau 2,2\%. Hal ini menunjukan bahwa komunikasi organisasi pegawai di Dinas Kependudukan 
dan Pencatatan Sipil Kota Banjarmasin Cukup Baik.

2) Kinerja pegawai di Dinas Kependudukan dan Pencatatan Sipil Kota Banjarmasin, yang termasuk dalam kategori Baik sebanyak 16 orang $(35,6 \%)$, sedangkan kategori Cukup Baik sebanyak 12 orang $(26,7 \%)$, kategori Kurang Baik 10 orang $(22,2 \%)$, serta kategori Sangat Baik sebanyak 4 orang $(8,9 \%)$, dan hanya ada 3 orang $(6,7 \%)$ yang termasuk kategori Tidak Baik. Hal ini menunjukan bahwa kinerja pegawai di Dinas Kependudukan dan Pencatatan Sipil kota Banjarmasin Baik.

3) Komunikasi organisasi dengan kinerja pegawai mempunyai nilai korelasi 0,298 dan nilai probabilitas 0,047 . Berdasarkan nilai korelasi 0,298 menunjukan terdapat hubungan atau korelasi antara komunikasi organisasi dengan kinerja, korelasi tersebut mempunyai sifat hubungan Rendah. Hasil probabilitas menunjukan bahwa $0,047<$ 0,05, hal ini menunjukan bahwa H0 ditolak, dengan demikian hipotesis $\mathrm{H} 1$ yang menyatakan terdapat hubungan antara komunikasi organisasi dengan kinerja pegawai di Dinas Kependudukan dan Pencatatan Sipil Kota Banjarmasin diterima. Jadi dapat disimpulkan bahwa apabila komunikasi organisasi pegawai membaik maka kinerja pegawai pun ikut membaik, demikian pula sebaliknya bila komunikasi organisasi pegawai kurang baik maka kinerja pegawai pun akan kurang baik.

\section{Saran}

Dari kesimpulan yang telah dikemukakan berdasarkan hasil analisis yang diperoleh maka ada beberapa saran-saran yang perlu dijadikan pertimbangan yaitu:

1) Berdasarkan hasil analisis tingkat komunikasi organisasi pegawai berada pada kategori Cukup Baik. Hal ini menandakan masih ada pegawai yang komunikasi organisasinya rendah. Oleh karena itu hendaklah Dinas Kependudukan dan Pencatatan Sipil Kota Banjarmasin terus meningkatkan komunikasi organisasi pegawainya.

2) Berdasarkan hasil analisis tingkat kinerja pegawai termasuk pada kategori Baik. Hal ini menandakan pegawai sudah lumayan optimal dalam melaksanakan dan menyelesaikan pekerjaannya. Oleh karena itu, diharapkan Dinas Kependudukan dan Pencatatan Sipil Kota Banjarmasin terus mempertahankan kinerja pegawainya dan alangkah baiknya lagi agar mengoptimalkan terus kinerja pegawai.
3) Dengan adanya hubungan antara komunikasi organisasi dengan kinerja pegawai, hendaknya semua pegawai di Dinas Kependudukan dan Pencatatan Sipil Kota Banjarmasin harus meningkatkan komunikasi organisasi yaitu baik dengan atasan maupun sesama rekan kerja dalam menjalankan tugas atau pekerjaan, agar tercapainya hasil kerja atau kinerja yang optimal.

\section{DAFTAR PUSTAKA}

1. Buku

Anwar, P. Mangkunegara. 2000. Manajemen Sumber Daya Manusia Perusahaan. Bandung : PT. Remaja Karya.

Bacal dan Robert (2012). Performance Management Terjemahan Surya Dharma dan Yanuar Irawan, Penerbit Gramedia Pustaka.

Djamaluddin, Arief. 2008. Pengembangan Sumber Daya Manusia dalam Persaingan Global. Jakarta: Pengembangan Bisnis dan Manajemen Global.

Fahmi, Irham. 2016. Manajemen Sumber Daya Manusia Teori dan Aplikasi. Bandung: ALFABETA.

Hasibuan, Malayu SP. 2009. Manajemen Sumber Daya Manusia. Jakarta: PT Bumi Aksara.

Liliweri, A. 2011. Komunikasi: Serba Ada Serba Makna. Jakarta: Kencana

Malthis, Robert L dan John H Jackson. 2001. Manajemen Sumber Daya Manusia. Jakarta: Salemba Empat.

Muhammad, A. 2009. Komunikasi Organisasi. Jakarta: Bumi Akasara. 2007. Komunikasi Organisasi. Jakarta: Bumi Akasara.

Pace, R Wayne. 1997. Komunikasi Organisasi Strategi Meningkatkan Kinerja Perusahaan. Bandung: PT. Remaja Rosda Karya.

Pratminingsih, Sri Astuti. (2006). Komunikasi Bisnis (Edisi pertama). Yogyakarta : Graha Ilmu.

Robbins, Stephen P. 2006. Prilaku Organisasi. Jakarta: Kelompok Gramedia.

Rohim, Syaiful. 2009. Teori Komunikasi. Jakarta: PT. Rineka Cipta.

Ruslan, Rosady. 2002. Manajemen Humas dan Manajemen Komunikasi, Edisi Revisi, Jakarta, PT. Raja Grafindo Persada.

Sinambela, Lijan P. 2016. Manajemen Sumber Daya Manusia; Membangun Tim Kerja yang Solid untuk Meningkatkan Kinerja. Jakarta: Bumi Aksara.

Sugiyono. 2012. Metode Penelitian Pendidikan (Pendekatan Kuantitatif, Kualitatif dan 
MUTAKALLIMIN; Jurnal Ilmu Komunikasi

Vol 3 No 2 November 2020

$R \& D)$. Bandung: ALFABETA. Sukmalana, Soelaiman. 2007. Manajemen Kinerja : Langkah Efektif untuk Membangun, Mengendalikan, dan Evaluasi Kinerja. Jakarta: PT. Intermedia Personalia Utama.

Silalahi, Ulber. 2011. Asas - Asas Manajemen. Bandung: Refika Aditama

Torang, Syamsir. 2014. Organisasi \& Manajemen (Perilaku, Struktur, Budaya \& Perubahan Organisasi). Bandung: ALFABETA.

Widodo, Suparno E. 2015. Manajemen Pengembangan Sumber Daya Manusia. Yogyakarta: PUSTAKA PELAJAR

Wirawan. (2012 ). Evaluasi Teori, Model, Standar, Aplikasi dan Profesi. Jakarta: Rajawali Pers.

\section{Skipsi dan Tesis}

Sehfudin, Arif. 2011. Pengaruh Antara

Komunikasi Organisasi Terhadap Kinerja Karyawan Pada PT Bank Tabungan Pensiunan Nasional Semarang. Skripsi. Semarang

Wahyuni, L. 2009. Pengaruh Komunikasi
Organisasi Terhadap Kinerja Karyawan Bagian Akuntansi Dengan Komitmen Organisasi Dan Tekanan Pekerjaan Sebagai Variabel Intervening (Studi Empiris Pada Perusahaan Bumn Di Provinsi Sumatera Barat). Tesis MM. Semarang : Universitas Deponegoro

Sunarcaya, P. 2008. Analisis Faktor-faktor yang mempengaruhi kinerja pegawai di lingkungan Dinas kesehatan Kabuppaten Alor NTT. Tesis MM. Jakarta : UT.

\section{Jurnal}

Harrison\&Doerfel in Islam\&Shiangtai (2006)The Antecendent Consequences of Utilization in International Srtategic alliance. Journal of International Business Disciplines, 3(1), diakses 2 September 2009. www.jibd.org

Haryanto, Agus B. 2010. Pengaruh Kompetensi, Motivasi, Komunikasi Dan Kesejahteraan Terhadap Kinerja Pegawai Dinas Pendidikan Kabupaten Sukoharjo. Jurnal Manajemen Sumberdaya Manusia Vol. 4 No. 148 Juni 2010: 47 - 57 